\title{
Application of roof bolting to reduce water inflow into mine workings during the crossing of tectonic faults
}

\author{
Oleksandr Krukovskyi ${ }^{1, *}$, Viktoriia Krukovska $^{1}$, Yurii Vynohradov ${ }^{2}$, and Vladimir Dyomin ${ }^{3}$ \\ ${ }^{1}$ Institute of Geotechnical Mechanics named by N. Poljakov of National Academy of Sciences of Ukraine, 2a Simferopolska Str., Dnipro, \\ 49005, Ukraine \\ ${ }^{2}$ Institute for Physics of Mining Processes of National Academy of Sciences of Ukraine, 2a Simferopolska Str., Dnipro, 49005, Ukraine \\ ${ }^{3}$ Karaganda Technical University, 56 Nursultana Nasarbaeva Ave., 100027, Kazakhstan
}

\begin{abstract}
In this work, the problem of water inflow reduction in Ukrainian coal mines, which are distinguished by difficult hydrogeological conditions, was considered. A numerical study of the change in water inflow into a mine working when it crosses a tectonic fault was carried out. The cases when the permanent working was supported by frame supports and roof bolts were considered. The calculation of stress fields, zones with inelastic deformations and coefficients of permeability, which depend on the stress state and takes into account tectonic and natural permeability of the rocks, was performed. The results of calculating the water pressure and water inflow into the mine working in all considered cases are presented in the article. Analysis of the calculated data showed that a disturbed area, which covered water-bearing ricks, was formed in the roof of the mine working with the frame support. Within this area, water can move towards the contour of the mine working. The filtration permeability of the host rocks increases significantly when the mine face approaches the tectonic disturbance. The flow rate of water reaches critical values. The use of roof bolting restrains the unloading of the boundary rocks from the rock pressure and keeps them in a triaxially compressed stress state. The permeability value decreases by the value of its technological component. In different areas of the intersection of tectonic disturbance, the water inflow into the mine working with roof bolting is 3-8 times less than in the working, supported by frame supports. Therefore, the use of roof bolting allows not only to keep the mine working in a stable state, but also to significantly reduce water inflows at complicated hydrogeological conditions.
\end{abstract}

\section{Introduction}

Ukrainian coal mines are notable for complicated geological conditions due to the great number of tectonic disturbances and flooded rocks. Different forms of geological structures, both plicate and disjunctive, characterize Donbas. Most of the Donbas coal mines are concentrated in large synclinal folds [1]. There is a failure of rocks integrity and an increase in their permeability in zones of local folding [2]. Permeability of rocks reaches its maximum in areas with the highest concentration of tectonic stresses [3]. Type and forming conditions of the faults determine their influence on the filtration properties of rocks. If joint fissures are formed under conditions of stretching of the earth's crust (mainly faults), then they increase permeability of the coal-bearing deposits in the zone adjacent to the fault [4].

The hydrogeological structure of the Western Donbas is a system of aquifers and complexes that cover the entire sedimentary layer and the upper part of the fractured zone of crystalline rocks. The total thickness of the flooded rocks ranges from $20 \mathrm{~m}$ to $1660 \mathrm{~m}$ and more, and it increases in the direction of rocks deepening to the axis of the Dnipro-Donetsk trough [5]. Water inflow into the mine workings mainly depends on the features of the geological structure of the mine fields and particularly on the tectonic disturbance of rocks, the number of aquifers, their thickness, pressure and filtration permeability [5-7]. For example, water production in the N.I. Stashkov Mine (the most water-flooded one in the Western Donbas) is $1640 \mathrm{~m}^{3} / \mathrm{h}$. When the edge rocks are flooded, they become soaked and their strength decreases. This leads to a loss of workings stability and requires additional finance for water extraction and supporting of mine workings [8-9].

In recent years, the researchers of the Institute of Geotechnical Mechanics named by N. Poljakov have done a lot of work to improve the roof bolting technology [10, 11]. The modified technology makes it possible to preserve the enclosing rocks in their natural, monolithic state and ensure reliable and safe functioning of mine workings throughout their operation [12]. The experience of coal production shows that technological operations can influence on filtration processes in the disturbed zone of the rock mass [13]. So, the use of roof bolting allows to prevent the process of crack formation in zone of the mine working influence and to reduce intensity of filtration flow [14-16].

\footnotetext{
$\overline{\text { * Corresponding author: igtm@ukr.net }}$
} 
In this article, the authors consider a possibility to use roof bolting in the mine workings in order to reduce water inflows from the undermined water-bearing rocks when crossing tectonic faults.

\section{Methods and problem definition}

Deformation of the coal-rock massif can be described by the equation:

$$
c_{g} \frac{\partial u_{i}}{\partial t}=\sigma_{i j, j}+X_{i}(t)+P_{i}(t)
$$

where $u_{\mathrm{i}}$ is displacements, $\mathrm{m} ; c_{g}$ is the damping coefficient, $\mathrm{kg} /\left(\mathrm{m}^{3} \cdot \mathrm{s}\right) ; \sigma_{\mathrm{ij}, \mathrm{j}}$ are the derivatives of the stress tensor components along $x, y, \mathrm{~Pa} / \mathrm{m} ; t$ is time, $\mathrm{s} ; X_{\mathrm{i}}(t)$ is projections of the external forces acting on the volume unit of solid body, $\mathrm{N} / \mathrm{m}^{3} ; P_{\mathrm{i}}(t)$ is projections of forces caused by gas pressure in the porous fractured space, $\mathrm{N} / \mathrm{m}^{3}$.

Deformation of rocks during mining operations leads to a change in their filtration permeability [17-20]. The change in the values of the permeability coefficients depending on the components of the principal stress tensor can be described as follows:

$$
k_{\text {tech }}=f\left(\sigma_{\mathrm{ij}}\right),
$$

where $k_{\text {tech }}$ is coefficient of permeability, which depends on the mine working driving, $\mathrm{D} ; f\left(\sigma_{\mathrm{ij}}\right)$ is a function which the authors defined in the work [19].
The process of water filtration in disturbed rocks is described by the following equation:

$$
\frac{\partial p}{\partial t}=\frac{K}{\mu \cdot \beta \cdot m_{p}}\left(\frac{\partial^{2} p}{\partial x^{2}}+\frac{\partial^{2} p}{\partial y^{2}}\right)+q(t),
$$

where $p$ is the water pressure, $\mathrm{Pa} ; K$ is the permeability coefficient, $\mathrm{D} ; \mu$ is water viscosity, $\mathrm{Pa} \cdot \mathrm{s} ; \beta$ is watercompressibility factor, $1 / \mathrm{Pa} ; q(t)$ is the water release function.

The coal and rocks are ground and have an initial tectonic permeability on 10-20 m from both sides of the fault. Some rock layers are also initially permeable and they have permeability $k_{\text {nat }}$. Technological permeability $k_{\text {tech, which is formed during the mine working driving and }}$ depends on the stress tensor components, is superimposed on the tectonic $k_{\text {tect }}$ and natural $k_{\text {nat }}$ permeability fields:

$$
K=k_{\text {tech }}+k_{\text {tect }}+k_{\text {nat }}
$$

As an example, let's consider a longitudinal section of a permanent working of $4 \mathrm{~m}$ high, which is driven at complicated conditions, similar to the conditions of the eastern main entry of the N.I. Stashkov Mine. There is a watered fractured coal band with a thickness of $0.4 \mathrm{~m}$ and watered sandstone with a thickness of $2.2 \mathrm{~m}$ in the mine roof. There is watered sandstone with a thickness of 0.8 $\mathrm{m}$ in the mine face. The permanent working intersects a disjunctive tectonic fault with displacement amplitude of $1 \mathrm{~m}$.

The central fragment of the finite element mesh for this problem is shown in Figure 1.

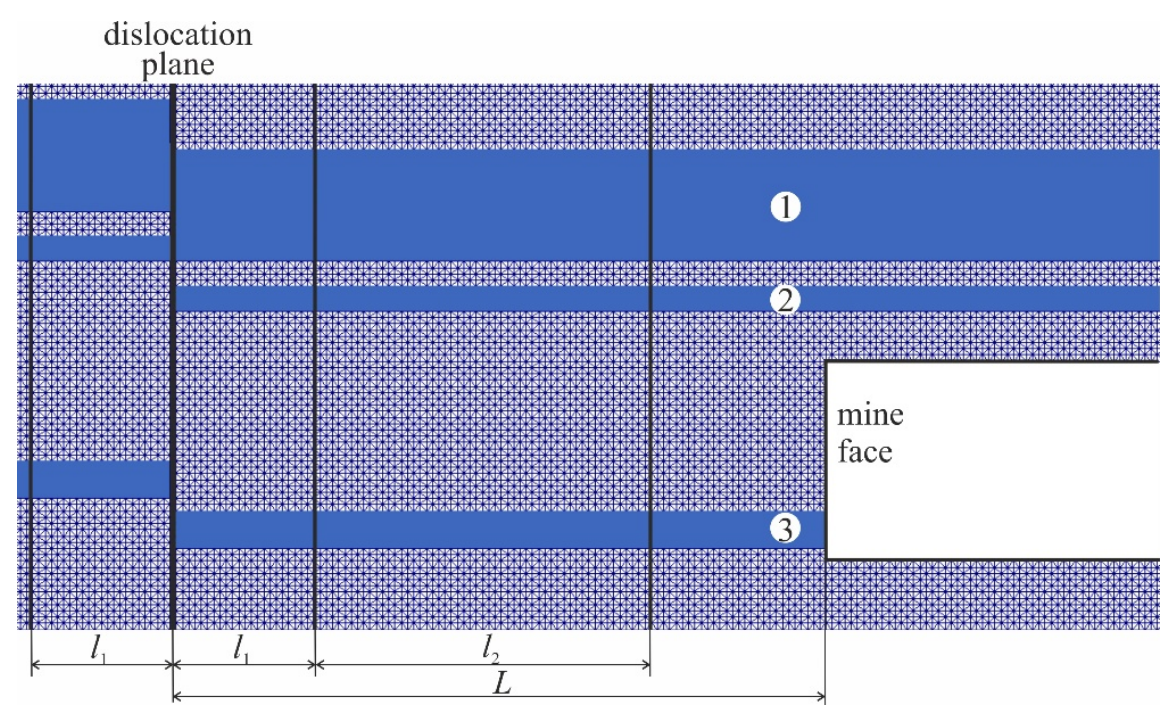

Fig. 1. The central fragment of the finite element mesh: 1,3-the watered sandstones; 2 - the watered fractured coal band.

The initial and boundary conditions for the task set:

$$
\begin{aligned}
&\left.\sigma_{y y}\right|_{t=0}=\gamma H ;\left.\quad \sigma_{x x}\right|_{t=0}=\lambda \gamma H ; \\
&\left.u_{x}\right|_{\Omega_{1}}=0 ;\left.\quad u_{y}\right|_{\Omega_{2}}=0 ; \\
&\left.p\right|_{\Omega_{3}}= 0.1 \mathrm{MPa} ;\left.\quad p\right|_{\Omega_{3}, t=0}=p_{0},
\end{aligned}
$$

where $\sigma_{x x}, \sigma_{y y}$ are components of the stress tensor, $\mathrm{Pa} ; \gamma$ is the average weight of the overlying mine rocks, $\mathrm{N} / \mathrm{m}^{3} ; H$ is the mining depth, $\mathrm{m} ; \lambda$ is the side thrust coefficient; $u_{x}$, $u_{y}$ are components of the displacement vector, $\mathrm{m} ; \Omega_{1}$ is vertical boundaries of the outer contour; $\Omega_{2}$ is horizontal boundaries of the outer contour; $\Omega_{3}$ is the contour of the permanent working; $\Omega_{4}$ are the watered sandstones and 
coal seam; $p_{0}$ is the water pressure in the virgin massif, $\mathrm{Pa}$.

The finite element method is widely used to solve geomechanics problems [21-23]. It is a powerful tool for simulating the coupled processes in rocks during mining operations. We solve the problems (1)-(4) with initial and boundary conditions (5) by the finite element method in the elastoplastic formulation by using the Coulomb-Mohr strength condition. To analyze the stress state of the rock massif, we use parameter $Q^{*}=\left(\sigma_{1}-\sigma_{3}\right) / \gamma H$. This parameter characterizes diversity of the stresses field components.

We assumed that initial permeability of the watered sandstones is $0.002 \mathrm{mDa}$, initial permeability of the watered coal band is $0.005 \mathrm{mDa}$; permeability in the area $l_{1}=3 \mathrm{~m}$ from displacement plane is $0.5 \mathrm{mDa}$; in the area $l_{2}=7 \mathrm{~m}$ is $0.1 \mathrm{mDa} ; p_{0}=3.5 \mathrm{MPa}$. Let's consider the cases when permanent working is supported by the frame support and roof bolting, and its face is located at different distance $L$ (Figure 1) from the tectonic fault:

a) $L=12 \mathrm{~m}, L>l_{1}+l_{2}$, the permanent working is outside the influence of tectonic fault;

b) $L=7 \mathrm{~m}, l_{1}<L<l_{1}+l_{2}$, the permanent working is in the slightly disturbed area;

c) $L=1 \mathrm{~m}, L<l_{1}$, the permanent working is located in the most disturbed zone of tectonic fault.

\section{Results and discussion}

\subsection{The stress state of the host rocks}

As a result of the modeling, fields of stresses and zones of inelastic deformations were obtained, Figure 2.

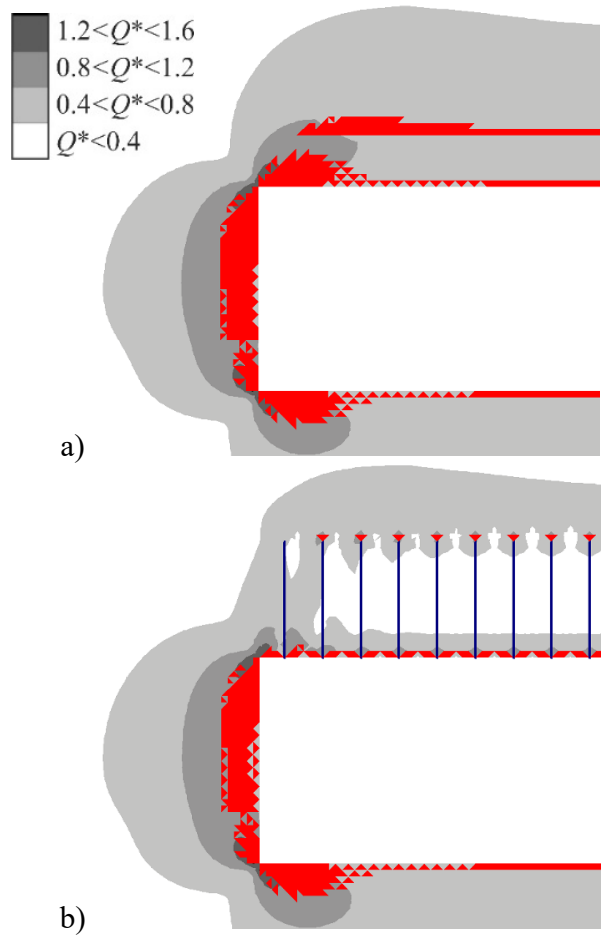

Fig. 2. The distribution of parameter $Q^{*}$ values and inelastic deformation zones: $a$ - the permanent working with frames; $b$ with roof bolting.
Hereinafter, the calculation results are given for $t=1$ day after the mine face movement.

The Figure 2 shows that area of increased diversity of the stress field components is formed around the mine working. Single defects, not interacting between each other, are accumulated in zone where $0.4<Q^{*}<0.8$. In areas where $0.8<Q^{*}<1.2$, the process of intense cracking develops. Here, uncontrolled growth of cracks takes place, and deformations rapidly increase due to the propagation of cracks and loosening of the rock [24]. Zone of inelastic deformation (is shown in red) surrounds the permanent working contour, hence, indicating the destruction of rocks.

In the mine roof with frame support (Figure $2 \mathrm{a}$ ), the disturbed zone includes both coal band and sandstone. Here, weak coal band is completely destroyed.

When using roof bolting (Figure $2 \mathrm{~b}$ ), zone of inelastic deformations is significantly reduced in boundary rocks of the roof and completely disappears in the coal band. In the anchored area, rocks and bolts form a slab, where $Q^{*}<0.4$. Here, both the rocks and the weak coal band are in a triaxially compressed state that keeps them from destruction.

\subsection{Filtration permeability of the host rocks}

The results of the permeability coefficient calculation are shown in Figures 3 and 4. In these figures, we can see dark zones of tectonic permeability and lighter zones of natural permeability in water-flooded sandstones and coal band.

A filtration area up to $2.4 \mathrm{~m}$ deep is formed in the mine roof with frame support (Figure 3) to where the watered coal band enters completely and sandstone enters partially. Inside this filtration area, water can move towards the contour of the mine. When the working face approaches the disjunctive disturbance, Figures $3 \mathrm{~b}$ and $3 \mathrm{c}$, it moves into the zone of disturbed rocks, which stratify easily and are destructed during undermining. The bearer support is not able to suppress this process, and filtration permeability is significantly increases in this zone.

Contours of the filtration area are changed when bolts are installed in the mine roof, Figure 4 . The use of roof bolting restrains the unloading of the boundary rocks from the rock pressure and keeps them in a triaxially compressed stress state. Therefore, in all cases of the mine face location relative to the tectonic fault plane, the resulting permeability $K$ decreases by the value of its technological component.

Outside of the influence of the tectonic fault (Figure $4 \mathrm{a}$ ), depth of permeable zone in the mine roof is reduced by 7-8 times in comparison with the same zone in Figure 3 a. The impermeable rock-bolt slab is preserved between the watered layers and the roof of the permanent working. As a result, the process of water filtration from aquifers into the mine working is inhibited.

In disturbed zone near the fault, action of the steelpolymer bolts only is not sufficient to form an impermeable slab. For this purpose, injection anchors, for example, could be used here. However, in the roof of the permanent working with roof bolting (Figures $4 \mathrm{~b}$ and 
$4 \mathrm{c}$ ), the permeability is significantly lower than in zone with the frame support (Figures $3 \mathrm{~b}$ and $3 \mathrm{c}$ ), which should reduce water inflow into the mine working in the hazardous zone.
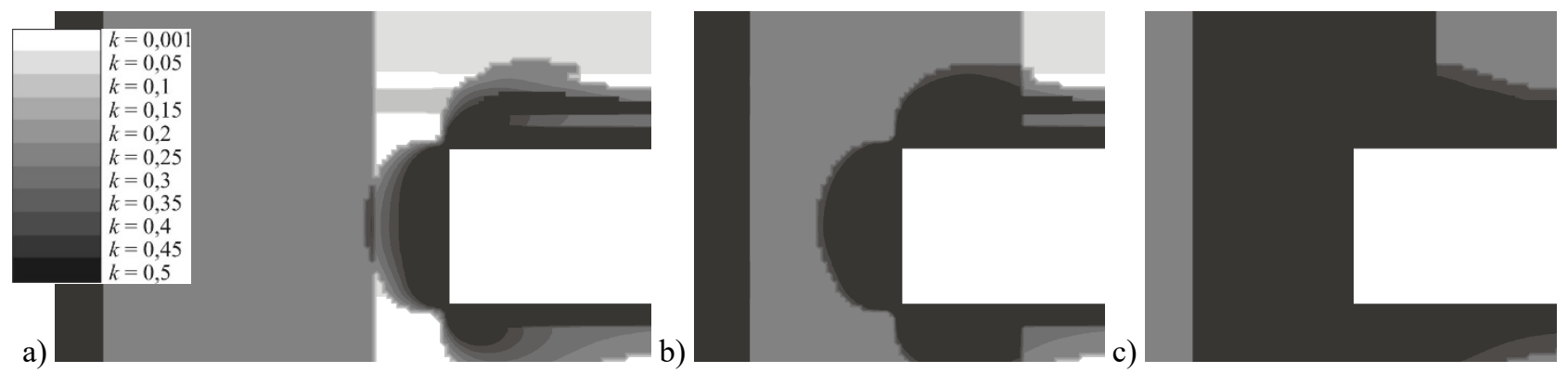

Fig. 3. The distribution of permeability coefficients around the permanent working with frame support: a) $L=12$ m, permanent working is outside of the fault influence; b) $L=7 \mathrm{~m}$; c) $L=1 \mathrm{~m}$.
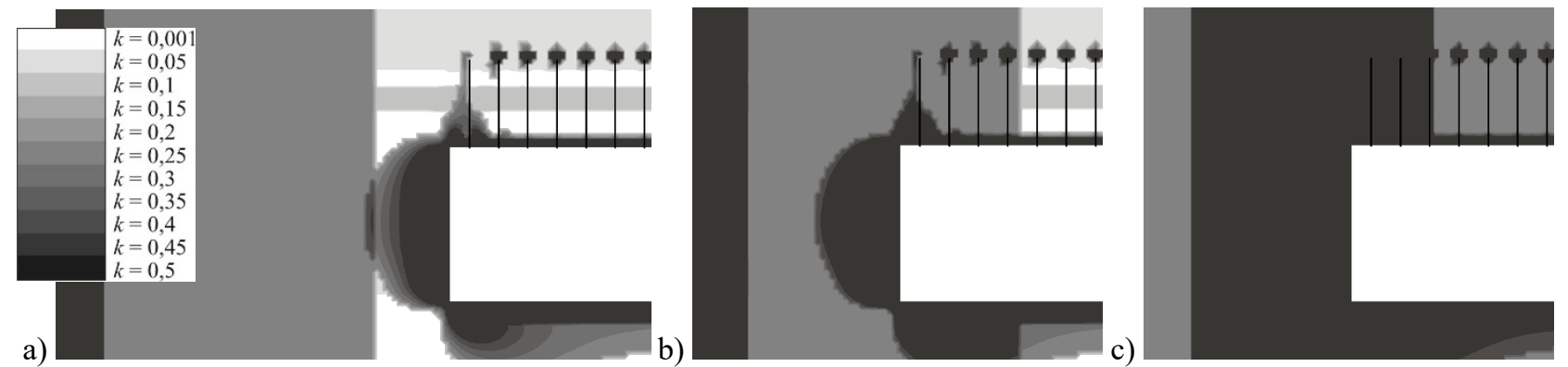

Fig. 4. The distribution of permeability coefficients around the permanent working with roof bolting: a) $L=12 \mathrm{~m}$, permanent working is outside of the fault influence; b) $L=7 \mathrm{~m}$; c) $L=1 \mathrm{~m}$.

\subsection{Analysis of changes in filtration parameters}

The distribution of water pressure values are shown in Figures 5 and 6 . It can be seen that water pressure in the watered beds near the fault is significantly reduced as compared with formation pressure, Figures $5 \mathrm{~b}$ and $6 \mathrm{~b}$. As practical experience shows, the increased permeability of rocks in zones of tectonic faults causes the movement of deep pressured water along the plane of displacement in the vertical direction.

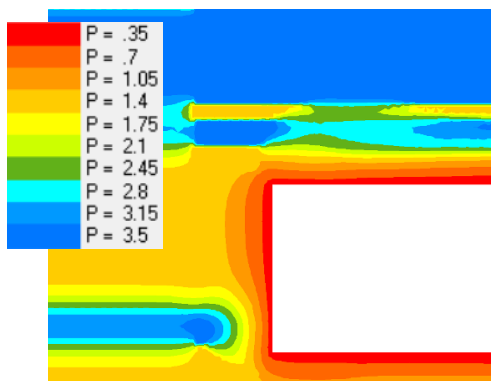

a)
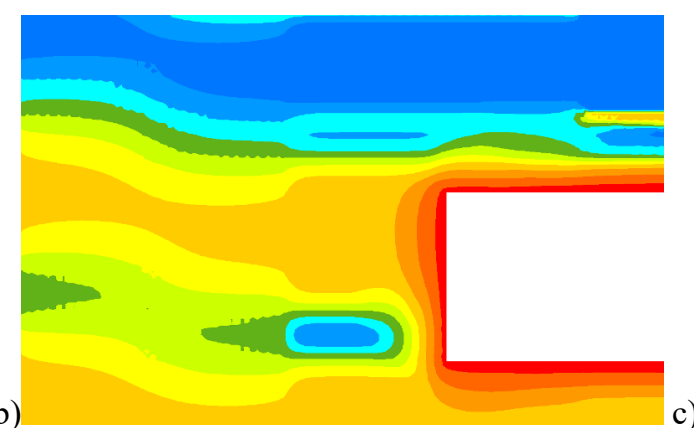

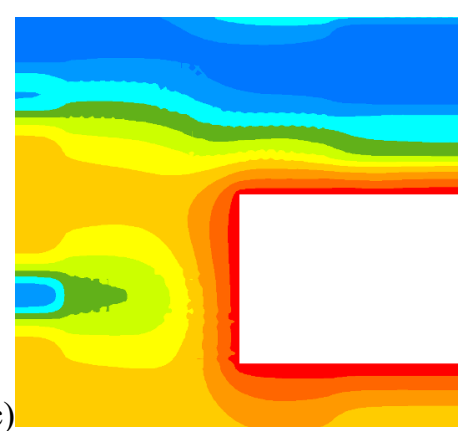

Fig. 5. Water pressure; permanent working with frame support: a) $L=12 \mathrm{~m}$; b) $L=7 \mathrm{~m}$; c) $L=1 \mathrm{~m}$.

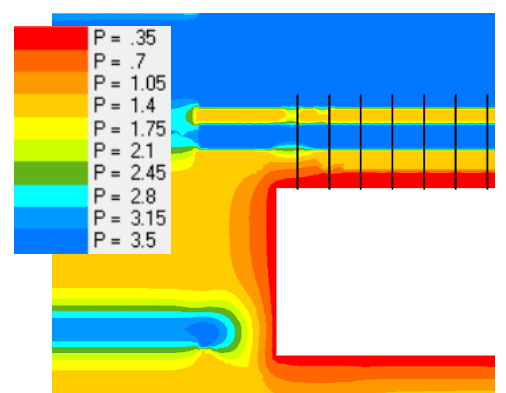

a)

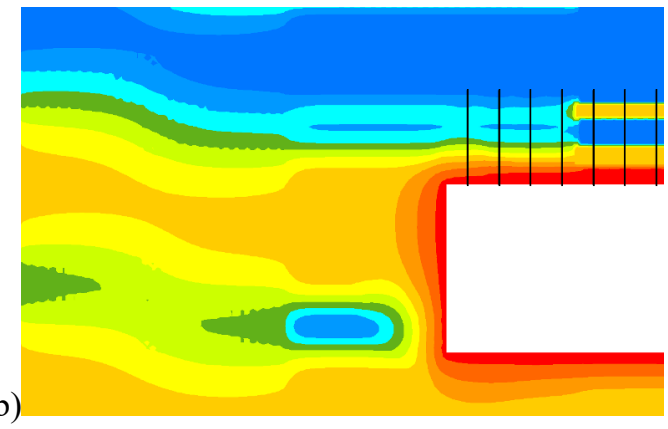

c)

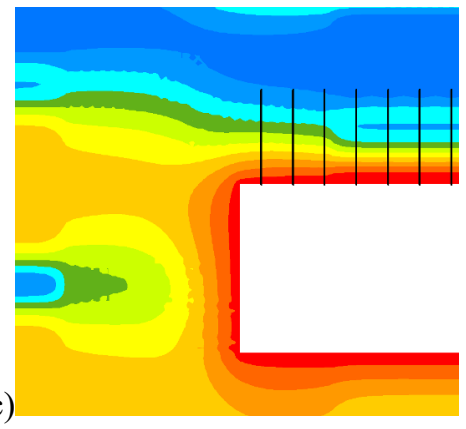

Fig. 6. Water pressure; permanent working with roof bolting: a) $L=12 \mathrm{~m}$; b) $L=7 \mathrm{~m}$; c) $L=1 \mathrm{~m}$. 
In the mine roof with frame support, the process of water filtration is actively taking place both outside the disturbed zone and near the tectonic fault. Water pressure in the undermined watered coal band and in part of sandstone decreases, Figure 5. Water moves from areas with higher pressure to the mine working where the pressure is minimal. When the mine face approaches the fault and enters the disturbed zone, the intensity of the filtration process increases, Figures $5 \mathrm{~b}$ and $5 \mathrm{c}$. The water inflow into the permanent working from the roof is doubled, Figure 7, and from the watered sandstone in the mine face increases by 1.5 times, Figure 8 .

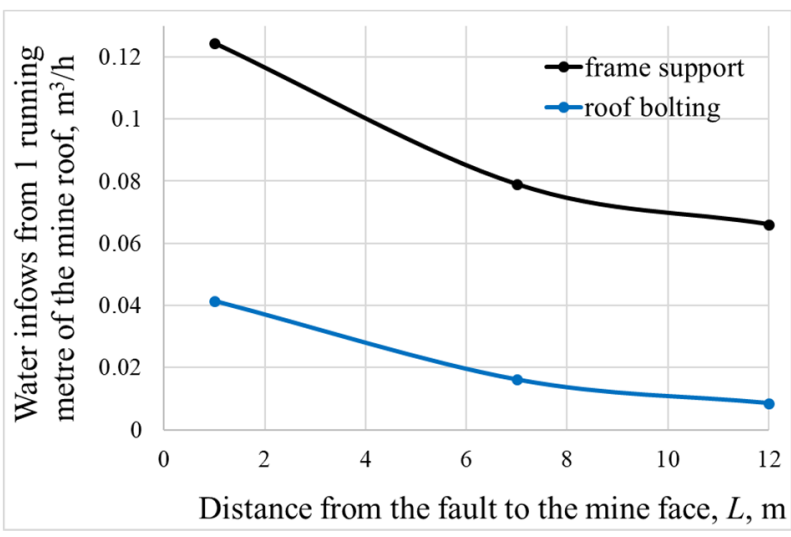

Fig. 7. Water inflow from the undermined roof rocks (per 1 running meter of permanent working).

If the roof bolting is used, the coal band pressure and sandstone pressure practically do not change in the mine roof, in the area outside the zone of influence of tectonic disturbance, Figure 6 a. This indicates a significant decrease in the intensity of the filtration process. The water inflow from the roof into the anchored mine working is almost 8 times less than into the mine working with frame supports, Figure 7 . We can assert that outside the zone of fault influence, the impermeable rock-bolt slab in the roof reduces water inflow into the mine working to a minimum.

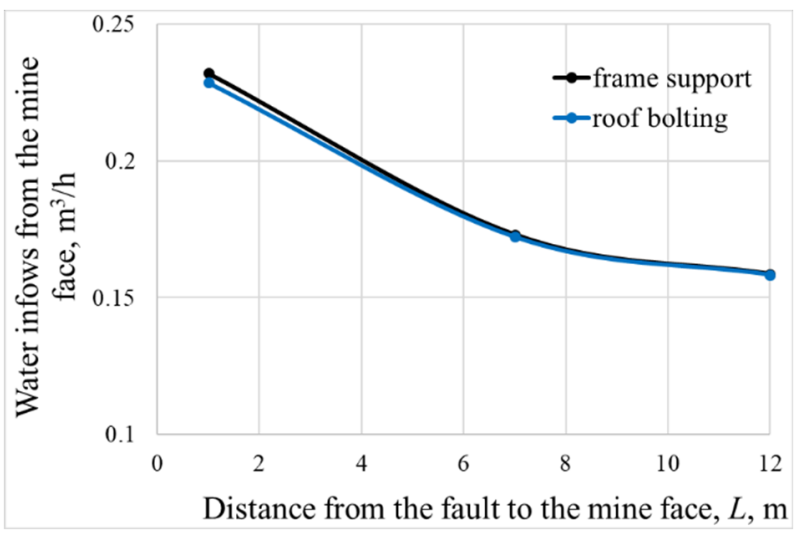

Fig. 8. Water inflow from the mine face.

When the mine face approaches the tectonic fault, where the roof rocks have already been disturbed as a result of tectonic impact, the roof bolts can only reduce the value of the filtration permeability by the value of $k_{\text {tech }}$.
However, this is sufficient to reduce the water inflow by 5 times at $L=7 \mathrm{~m}$ and by 3 times at $L=1 \mathrm{~m}$, Figure 7 .

The water flow rate from the watered sandstone in the mine working face increases by 1.5 times when it approaches the fault and does not depend on the kind of roof supporting, Figure 8.

Roof bolting in mine workings at difficult hydrogeological conditions, when they cross tectonic faults, allows to reduce permeability of tectonically disturbed host rocks, slow down the water filtration process and reduce water inflow from the undermined watered rocks into the mine workings by 3-5 times. Outside the zone of disturbance influence, an impermeable rock-bolt slab in the mine roof stops water inflow into the mine working almost completely.

\section{Conclusions}

The problem of water inflow reduction in Ukrainian coal mines, which are distinguished by difficult hydrogeological conditions, was considered. A numerical study of the change in water inflow into the mine working when it crosses a tectonic fault was carried out. The cases when permanent working was supported with frame supports and roof bolts were considered.

Stress fields, zones of inelastic deformations and permeability coefficients, which depended on the stress state and took into account tectonic and natural permeability of rocks, were calculated. The results of calculation of water pressure and water inflow into the mine working in all considered cases are presented.

Analysis of the calculated data shows that filtration area, which covers water-bearing rocks, is formed in the roof of the mine working with frame support. Within this area, water can move towards the contour of the mine working. Filtration permeability of the host rocks increases significantly when the mine face approaches the tectonic disturbance. The flow rate of water reaches critical values.

The use of roof bolting restrains the unloading of the boundary rocks from the rock pressure and keeps them in triaxially compressed stress state. Permeability value decreases by the value of its technological component. In different areas of the intersection of tectonic disturbance, water inflow into the mine working with roof bolting is 38 times less than in the working with the frame supports. Therefore, the use of roof bolting allows not only to keep the mine working in a stable state, but also to significantly reduce water inflows at complicated hydrogeological conditions.

\section{References}

1. V.I. Nikolin, I.I. Balinchenko, A.A. Simonov, Borba $s$ vyibrosami uglya i gaza v shahtah (Nedra, Moscow, 1981)

2. V.V. Lukinov, K.O. Bezruchko, O.V. Prykhodchenko. Coal of Ukraine 1 (2018)

3. V.G. Zhoglo, S.I. Grimus, A.V. Haletskiy. SOCAR Proceedings 2 (2010) 
4. A.F. Bulat, V.V. Lukinov, K.O. Bezruchko, Umovy formuvannia hazovykh pastok u vuhlenosnykh vidkladakh (Naukova dumka, Kyiv, 2017)

5. V.O. Sotskov, A.M. Zahrytsenko, N.I. Dereviahina. Scientific notes of Taurida National V.I. Vernadsky University. Series: Technical Sciences 6, 2 (2019)

6. H. Masoumi, J. Horne, W. Timms. Rock Mech. \& Rock Eng. 50, 8 (2017)

7. H. Liu, W. Zhu, Y. Yu, T. Xu, R. Li, X. Liu. Int. J. Rock Mech. \& Min. Sci. 127 (2020)

8. T. Yang, W. Zhu, Q. Yu, H. Liu. Hydrogeol. J. 19, 5 (2011)

9. Li L, Yang T, Liang Z, Zhu W, Tang C. Int. J. Coal Geol. 85, 3-4 (2011)

10. A.F. Bulat, V.V. Vinogradov, Oporno-ankernoe kreplenie gornyih vyirabotok ugolnyih shaht (Vilpo, Dnepropetrovsk, 2002)

11. O. Krukovskyi, Y. Bulich, Y. Zemlianaia. E3S Web of Conferences 109, 00042 (2019)

12. System of providing reliable and safe functioning of roof bolting mine workings. General technical requirements (Ministry of Energy and Coal Mining of Ukraine, Kyiv, 2014)

13. A.V. Ahafonov, Sposobyi i sredstva obespecheniya bezopasnosti provedeniya podgotovitelnyih vyirabotok po vyibrosoopasnyim plastam (Donbass, Donetsk, 1998)

14. V. Krukovska, Y. Vynohradov. E3S Web of Conferences 109, 00041 (2019)

15. R.S. Yang, Y.L. Li, D.M. Guo, L. Yao, T.M. Yang, T.T. Li. Int. J. Min. Sci. Technol. 27, 2 (2017)

16. W. Nie, Z.Y. Zhao, S.Q. Ma, W. Guo. Tunn. Undergr. Space Technol. 71 (2018)

17. D.H. Steve Zou, Yu Chuxin, Xian Xuefu. Int. J. Rock Mech. \& Min. Sci. 36 (1999)

18. M. Bai, F. Meng, D. Elsworth, M. Zaman, J.-C. Roegiers. Int. J. Rock Mech. \& Min. Sci. 34, 3-4 (1997)

19. V.V. Krukovska, O.P. Krukovskyi, Yu.O. Vinogradov. Geotechnical Mechanics 120 (2015)

20. F.M.R. Ferfera, J-P. Sarda, M. Bouteca, O. Vincke. Int. J. Rock Mech. \& Min. Sci. 34, 3-4 (1997)

21. O.C. Zienkiewicz, R.L. Taylor, J.Z. Zhu. The Finite Element Method: Its Basis and Fundamentals (Butterworth-Heinemann, London, 2013)

22. M. Stupnik, O. Kalinichenko, V. Kalinichenko, S. Pysmennyi, O. Morhun. Mining of Mineral Deposits 12, 4 (2018)

23. S. Pysmennyi, M. Fedko, N. Shvaher, S. Chukharev. E3S Web of Conferences 201, 01022 (2020)

24. V.V. Vynohradov, Geomehanika upravleniya sostoyaniem massiva vblizi gornyih vyirabotok (Naukova dumka, Kyiv, 1989) 